\title{
Upaya Pemberdayaan Usaha Mikro Kecil Menengah (UMKM) Dalam Mengatasi Kemiskinan Dikecamatan Tugumulyo Kabupaten Musi Rawas
}

\author{
Miki Indika \\ Universitas Musi Rawas \\ Email: miki_indika@yahoo.com \\ Yayuk Marliza \\ Universitas Musi Rawas \\ Email:marlizayayuk@gmail.com
}

\begin{abstract}
The problem of poverty is a complex problem faced by all countries including Indonesia and the problem is the optimal use of resources. In Musi Rawas Regency poverty is also one of the problems faced in the success of development. This study aims to determine the role of Micro, Small and Medium Enterprises in overcoming poverty in Tugumulyo District, Musi Rawas Regency. In this study a qualitative method was used to determine the role of MSMEs in overcoming poverty and the approach to be taken so as to create synergy between MSMEs and the community in poverty alleviation efforts. The problem in empowering MSMEs in the Tugumulyo sub-district is the problem of lack of capital, but MSMEs are reluctant to come to banks especially because they are related to the many requirements needed to obtain credit facilitation from banks. Conversely, often financial institutions face the problem of how to market the "capital" collected from the community so that it can be channeled to MSME entrepreneurs safely. Efforts to empower MSMEs in order to overcome poverty in the Tugumulyo sub-district are through internal development of MSME managers, namely the provision of capital, product innovation and network expansion. It is also supported by external development from the government, namely the provision of training and guidance and expansion of product marketing with assistance from the Musi Rawas Cooperative and SME Office. As the main sector of employment, the progress of MSMEs will have a significant impact on improving the welfare of the people involved in it, so the number of poor people will decline.
\end{abstract}

Keywords: Empowerment of Micro and Small and Medium Enterprises, Poverty

\begin{abstract}
Abstrak
Masalah kemiskinan merupakan masalah yang rumit yang dihadapi oleh semua negara termasuk Indonesia dan yang menjadi kendalanya adalah dalam pemanfaatan sumber daya secara optimal. Di Kabupaten Musi Rawas kemiskinan juga merupakan salah satu persoalan yang dihadapi dalam keberhasilan pembangunan. Penelitian ini bertujuan mengetahui peranan Usaha Mikro Kecil Menengah dalam mengatasi kemiskinan di Kecamatan Tugumulyo kabupaten Musi Rawas. Dalam penelitian ini digunakan metode kualitatif agar diketahui peranan UMKM dalam mengatasi kemiskinan serta pendekatan yang akan dilakukan agar tercipta sinergi antara UMKM dan masyarakat dalam upaya pengentasan kemiskinan. Permasalahan dalam pemberdayaan UMKM di kecamatan Tugumulyo ini adalah masalah kekurangan modal, namun UMKM enggan untuk datang ke bank khususnya karena terkait oleh banyaknya persyaratan yang diperlukan untuk memperoleh fasilitasi kredit dari perbankan. Sebaliknya sering lembaga keuangan menghadapi masalah bagaimana memasarkan "modal" yang dihimpun dari masyarakat tersebut agar dapat tersalur kepada pengusaha UMKM dengan aman. Upaya pemberdayaan UMKM dalam rangka mengatasi kemiskinan di kecamatan Tugumulyo yaitu melalui pengembangan secara internal dari pengelola UMKM yaitu pengadaan permodalan, inovasi hasil produk dan perluasan jaringan. Selain itu juga didukung oleh pengembangan secara eksternal dari pihak pemerintah yaitu pengadaan pelatihan dan pembinaan serta perluasan pemasaran produk dengan pendampingan dari Dinas Koperasi dan UKM Kabupaten Musi Rawas. Sebagai sektor utama penyerapan tenaga kerja, kemajuan UMKM akan memberikan dampak yang signifikan bagi peningkatan kesejahteraan masyarakat yang terlibat di dalamnya, sehingga jumlah penduduk miskin akan menurun.
\end{abstract}




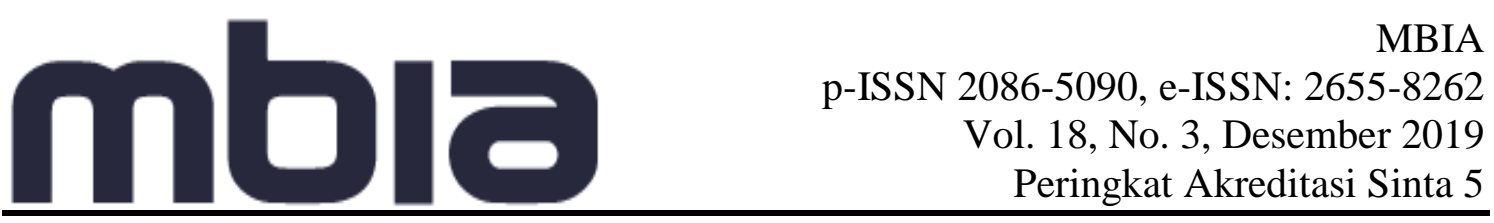

Kata kunci: Pemberdayaan Usaha Mikro Kecil dan Menengah, Kemiskinan

\section{Pendahuluan}

Kemiskinan di Negara sedang berkembang menjadi masalah yang sangat rumit diselesaikan meskipun kebanyakan Negara-negara ini sudah berhasil melaksanakan pembangunan ekonominya dengan tingkat pertumbuhan produksi dan pendapatan nasional yang tinggi, namun pada saat yang bersamaan telah terjadi peningkatan ketimpangan distribusi pendapatan antar kelompok kaya dan kelompok miskin. Dewasa ini kemiskinan pedesaan menjadi masalah utama dalam proses pelaksanaan pembangunan di daerah pedesaan, karena sebagian besar penduduk miskin tinggal di daerah pedesaan dan karakteristik penyebab kemiskinan struktural yang dialami sangat banyak.

Sebenarnya, masalah kemiskinan merupakan masalah yang rumit yang dihadapi oleh semua negara termasuk Indonesia dan yang menjadi kendalanya adalah dalam pemanfaatan sumber daya secara optimal. Di Kabupaten Musi Rawas kemiskinan juga merupakan salah satu persoalan yang dihadapi dalam keberhasilan pembangunan. Berdasarkan informasi yang diperoleh dari hasil Survei Sosial Ekonomi Nasional (SUSENAS) Tahun 2016 menempatkan kabupaten Musi Rawas sebagai kabupaten termiskin ke-12 dari 17 kabupaten kota se Sumatera Selatan. Meski tak mengalami perubahan secara peringkat, namun angka persentase kemiskinan di Bumi Lan Serasan Sekentenan itu pada tahun 2016 mengalami penurunan dibanding tahun 2015 lalu. Pada tahun 2015 angka kemiskinan mencapai 15,13 persen, sementara pada tahun 2016 angka kemiskinan turun menjadi 14,30 persen atau sebesar 55.500 jiwa dari 58.000 jiwa dengan total jumlah penduduk kabupaten Musi Rawas sebesar 407.000 jiwa. Dari 14,30 persen itu rata-rata didominasi oleh petani dengan tingkat penghasilan kurang dari 400 ribu per bulan. (Aidil Adha, BPS, 2017).

Pada tahun 2015 secara persentase paling banyak penduduk miskinnya berada dikecamatan Selangit, sementara secara jumlah penduduk yang paling banyak penduduk miskin berada diwilayah kecamatan Megang Sakti dan Tugumulyo, karena Megang Sakti dan Tugumulyo, kebutuhannya banyak dan penduduknya sangat padat, berbeda dengan kecamatan Selangit yang jumlah penduduknya sedikit. Penyebab turunnya indeks kemiskinan di kabupaten Musi Rawas dikarenakan beberapa program pemerintah sudah mulai berjalan dan mulai dirasakan dampaknya oleh masyarakat. Dari sejumlah program pemerintah itu, program yang paling berpengaruh yakni sektor pendidikan seperti program MURA cerdas dan program peningkatan ekonomi seperti program MURA menanam.

Kemiskinan merupakan permasalahan sosial yang memiliki pengaruh terhadap berbagai permasalahan di masyarakat seperti kriminalitas, perceraian dan lain-lain, Hasil wawancara dengan Kasi Kesos Kecamatan Tugumulyo, Ibu Nurbaiti, S.E bahwa pada wilayah Kecamatan Tugumulyo terdapat 4 (empat) Desa yang terkategori sebagai Desa tertinggal yaitu Desa Dwijaya, Nawangsasi, Wonokererto dan Wukir Sari. Selanjutnya dari hasil observasi ke 4 (empat) Desa tersebut diketahui mayoritas penduduk di Desa tersebut bermata pencaharian sebagai petani padi dan karet.

Kemiskinan apabila dipandang dari sisi ekonomi muncul karena adanya ketidaksamaan pada kepemilikan sumber daya yang menimbulkan distribusi pendapatan yang timpang, perbedaan dalam kualitas sumber daya manusia dan perbedaan akses dalam modal serta rendah kesempatan kerja yang ada. Tingginya tingkat kemiskinan menjadi indikator bahwa masyarakat belum berperan menjadi subjek dalam pembangunan. 
Berbicara mengenai masalah ekonomi kerakyatan tidak akan pernah lepas dari pembicaraan tentang UMKM. UMKM menjadi pembahasan berbagai pihak karena UMKM dianggap sebagai penyelamat perekonomian dimasa krisis pada periode 1998 - 2000 dan UMKM pun menjadi perhatian pemerintah dengan dibuatnya sebuah kementrian dan digabung dengan koperasi yang selama ini diperjuangkan.

Pengembangan ekonomi kerakyatan harus diprioritaskan melalui keberpihakan kepada sektor UKM. Sekarang ini pemerintah berusaha mendorong UKM untuk terus tumbuh sehingga bisa lebih banyak menyerap tenaga kerja. Selanjutnya UMKM mempunyai peran yang strategis dalam pembangunan ekonomi nasional. Selain berperan dalam pertumbuhan ekonomi dan penyerapan tenaga kerja juga berperan dalam pendistribusian hasil-hasil pembangunan dan harus kita akui bahwa UMKM mempunyai suatu peran yang sangat vital didalam pembangunan dan pertumbuhan ekonomi tidak hanya dinegara sedang berkembang tapi juga di negara maju. Peran yang sangat penting ini terlihat dari perspektif kesempatan kerja dan sumber pandapatan bagi kelompok miskin, distribusi pendapatan, pengurangan kemiskinan dan pembangunan perekonomian.

Mengingat hal diatas sudah saatnya pemberdayaan masyarakat dalam ekonomi rakyat menjadi perhatian utama. Disini diharapkan masyarakat menjadi semakin dituntut untuk aktif berperan dan bekerja lebih giat lagi untuk memenuhi kebutuhan hidupnya dengan layak, dapat meningkatkan kesejahteraannya dan akhirnya akan mengurangi tingkat kemiskinan. Disamping itu pemberdayaan UMKM banyak menghadapi permasalahan yaitu kesulitan terhadap permodalan, tehnologi, rendahnya kualitas sumber daya manusia, mahalnya harga bahan baku dan banyaknya pesaing yang bergerak dalam bisnis yang sama. Mengingat hal tersebut maka pembangunan ekonomi harus menuju pada sistem ekonomi rakyat yaitu UMKM. Kedudukan dan posisi UMKM perlu ditingkatkan dan pemberdayaan UMKM sebagai sarana pengentasan kemiskinan merupakan salah satu alternatif yang harus segera dilakukan. Berdasarkan latar belakang diatas terlihat bahwa pemberdayaan UMKM perlu dilakukan untuk mengatasi kemiskinan di Kecamatan Tugumulyo Kabupaten Musi Rawas.

\section{Literature Review}

\subsection{Definisi Kemiskinan}

Secara umum kemiskinan lazim didifinisikan sebagai kondisi dimana seseorang tidak dapat memenuhi kebutuhan dasarnya dalam rangka menuju kehidupan yang lebih bermartabat. Kemiskinan merupakan masalah kompleks yang dipengaruhi oleh berbagai faktor yang saling berkaitan antara lain tingkat pendapatan, kesehatan, pendidikan, akses terhadap barang dan jasa, lokasi geografis, gender dan kondisi lingkungan.

Definisi beranjak dari pendekatan berbasis hak yang menyatakan bahwa masyarakat miskin mempunyai hak-hak dasar yang sama dengan anggota masyarakat lainnya. Kemiskinan tidak lagi dipahami hanya sebatas ketidakmampuan ekonomi, tetapi juga kegagalan memenuhi hak-hak dasar dan perbedaan perlakuan bagi seseorang atau kelompok orang dalam menjalani kehidupan secara bermartabat.

Hak-hak dasar yang diakui secara umum adalah terpenuhinya kebutuhan pangan, kesehatan, pendidikan, pekerjaan, perumahan, air bersih, pertanahan dan lingkungan hidup, rasa aman dari perlakuan atau ancaman tindak kekerasan dan hal-hal untuk berpartisipasi dalam kehidupan sosial politik baik perempuan maupun laki-laki. Parameter yang lazim digunakan para analis dalam menetapkan jumlah kemiskinan 


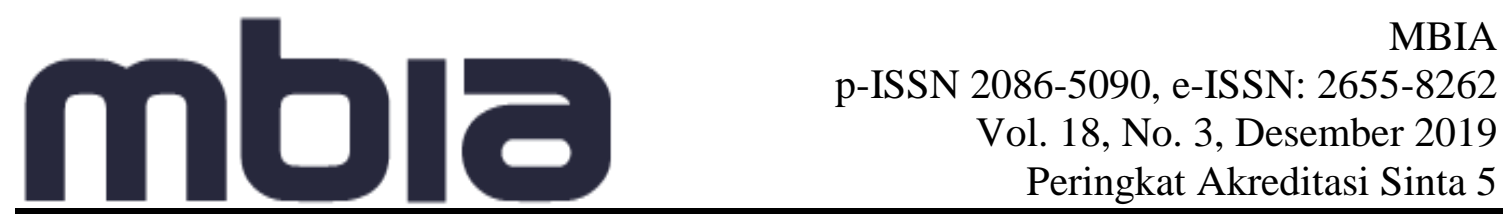

adalah lebih cenderung pada pendekatan pemenuhan kebutuhan pokok. Dari hal ini, seseorang dikatakan miskin manakala dalam pemenuhan kebutuhan pokoknya yakni makanan, asupan kalorinya minimal $2.100 \mathrm{kkal} / \mathrm{hari}$ per kapita. Selain dengan pendekatan asupan kalori, kemiskinan juga diukur dengan menambahkan parameter pemenuhan kebutuhan pokok/dasar non makanan yang meliputi pendidikan, sandang dan hal-hal yang dikemukakan di atas.

Dari sini, dapat kita katakan bahwa dalam menentukan kemiskinan terdapat variabel pokok yang tidak bisa dilupakan yakni yang terkenal dengan istilah gari kemiskinan (GK). Garis kemiskinan ini terbagi menjadi dua yakni Garis Kemiskinan Makanan (GKM) dan Garis Kemiskinan Bukan Makanan (GKBM). Adapun komponen dari masing-masing indikator adalah GKM lebir berbasis pada pendekatan pemenuhan asupan kalori sebesar $2.100 \mathrm{kkal} / \mathrm{hari}$ per kapita. Sedangkan komponen GKBM adalah seperti pendidikan, kesehatan dan papan.

\subsection{Penyebab Kemiskinan}

Ada banyak penyebab kemiskinan. Sharp dalam Kuncoro (2004), mencoba mengidentifikasikan penyebab kemiskinan dipandang dari sisi ekonomi. Menurut Sharp, penyebab munculnya kemiskinan bisa dilihat dari sudut pandang Mikro. Secara Mikro ada tiga penyebab munculnya kemiskinan, antara lain ; (1) Kemiskinan muncul karena adanya ketidaksamaan pola kepemilikan sumberdaya yang menimbulkan distribusi pendapatan yang timpang. Penduduk miskin hanya memiliki sumberdaya dalam jumlah terbatas dan kualitasnya rendah, (2) Kemiskinan muncul akibat perbedaan dalam kualitas sumberdaya manusia. Kualitas sumberdaya manusia yang rendah berarti produktifitasnya rendah, yang pada gilirannya upahnya rendah. Rendahnya kualitas sumberdaya manusia ini karena rendahnya pendidikan, nasib yang kurang beruntung, adanya diskriminasi, atau karena keturunan dan (3) Penyebab kemiskinan ini bermuara pada teori lingkaran setan kemiskinan (vicious circle of poverty).

Adanya keterbelakangan, ketidaksempurnaan pasar, dan kurangnya modal menyebabkan rendahnya produktivitas mengakibatkan rendahnya pendapatan yang mereka terima. Rendahnya pendapatan berimplikasi pada rendahnya tabungan dan investasi. Rendahnya investasi berakibat pada keterbelakangan, ketertinggalan dan ketidaksempurnaan pasar. Logika berfikir ini dikemukanoleh Ragnar Nurkse dalam Kuncoro (2006), yang mengatakan "a poor country is poor because it is poor" (suatu negara miskin menjadi miskin karena negara tersebut memang miskin).

Banyak perspektif yang yang menjelaskan bentuk-bentuk kemiskinan. Menurut Jamasy (2004) Jika dilihat dari penyebabnya, kemiskinan dapat dibagi menjadi dua kelompok, yaitu: kemiskinan kultural dan kemiskinan structural. Kemiskinan kultural merupakan suatu kondisi kemiskinan yang terjadi karena kultur, budaya atau adat istiadat yang dianut oleh suatu kelompok masyarakat. Kebiasaan masyarakat yang merasa cepat puas akan sesuatu yang telah dicapai, sifat bermalas-malasan dan cara berpikir masyarakat yang kurang rasional dapat menyebabkan terjadinya kemiskinan pada masyarakat kelompok ini. Kemiskinan kultural atau ada beberapa ahli yang menyebut dengan budaya kemiskinan. Budaya kemiskinan pada suatu kelompok masyarakat sebagai suatu kondisi dalam suatu kelompok masyarakat yang menurut pandangan kelompok masyarakat lain 


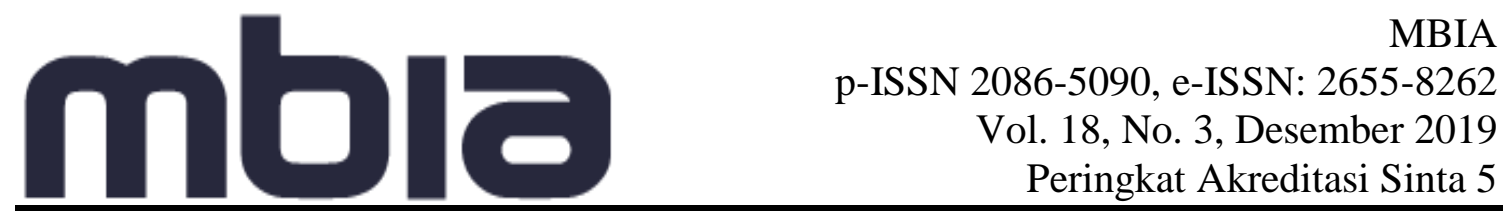

kondisinya sangat miskin serba kekurangan dan perlu pertolongan segera, namun kelompok masyarakat itu sendiri merasa biasa-biasa saja bahkan "enjoy" dengan keadaannya. Hal inilah yang menyebabkan pihak-pihak lain atau kita akan kesulitan untuk mengetaskan kemiskinan pada kelompok ini.

Kemiskinan struktural adalah kondisi atau situasi miskin karena pengaruh kebijakan pembangunan yang belum menjangkau seluruh masyarakat sehingga menyebabkan ketimpangan pendapatan. Kemiskinan struktural muncul karena ketidakmampuan sistem dan struktur sosial dalam menyediakan kesempatan-kesempatan yang memungkinkan si miskin dapat bekerja. Struktur sosial tersebut tidak mampu menghubungkan masyarakat dengan sumber-sumber yang tersedia, baik yang disediakan oleh alam, pemerintah maupun masyarakat yang ada disekitarnya. Mereka yang tergolong dalam kelompok ini adalah buruh tani, pemulung, penggali pasir dan mereka yang tidak terpelajar dan tidak terlatih. Pihak yang berperan besar dari terciptanya kemiskinan struktural adalah pemerintah. Sebab, pemerintah yang memiliki kekuasaan dan kebijakan cenderung membiarkan masyarakat dalam kondisi miskin, tidak mengeluarkan kebijakan yang pro masyarakat miskin, Kalau pun ada lebih berorientasi pada proyek, bukan pada pembangunan kesejahteraan, sehingga tidak ada masyarakat miskin yang 'naik kelas'. Artinya jika pada awalanya sebagai buruh, nelayan, pemulung, maka selamanya menjadi buruh nelayan dan pemulung.

\subsection{Potret Pembiayaan terhadap Sektor UMKM}

Di tengah terpaan krisis energi, pangan dan keuangan yang sedang melanda dunia, termasuk didalamnya Indonesia, perhatian pemerintah terhadap sector UMKM kian menampakkan perkembangan yang menggembirakan. Adapun pinjaman dengan plafon di atas Rp 5 miliar disebut kredit korporasi. Membesarnya porsi kredit UMKM tidak terlepas dari gencarnya penyaluran Kredit Usaha Rakyat (KUR). KUR merupakan kredit program yang diluncurkan Presiden Susilo Bambang Yudhoyono pada November 2007. KUR ditujukan bagi pengusaha mikro dan kecil yang tidak memiliki agunan tambahan dengan plafon maksimal Rp 500 juta. Bank bersedia menyalurkan KUR karena kreditnya dijamin oleh pemerintah yang dalam hal ini yang ditunjuk adalah Askrindo dan Perum Sarana Pengembangan Usaha.Beberapa bank yang di gandeng oleh pemerintah dalam menyalurkan dana ini antara lain BRI, BTN, BNI, Bank Mandiri, Bukopin, Bank Pembangunan Daerah dan Bank Syariah Mandiri. Data Komite KUR menunjukkan sektor perdagangan mendominasi penyaluran dana yaitu mencapai Rp. 65,691 triliun dengan 5,793 debitur. Berikutnya sektor pertanian dengan penyaluran dana sebesar Rp. 18, 971 triliun bagi 1,263 debitur. Bank BRI menjadi penyalur KUR terbesar yaitu Rp. 70,4 triliun, terdiri dari KUR ritel Rp. 14,441 triliun untuk 87,659 debitur dan KUR Mikro Rp. 54,005 triliun untuk 7,929 debitur.

Dari data di atas kiranya kita patut optimis bahwa perhatian pemerintah terhadap kesejahteraan rakyatnya, yang ditandai oleh besarnya porsi penyaluran kredit terhadap sektor UMKM menunjukkan peningkatan. Dengan kondisi demikian, lambat laun permasalahan kemiskinan di Indonesia dapat tertanggulangi sedikit demi sedikit. Tentu saja hal ini harus di barengi dengan komitmen segenap komponen bangsa terlebih bagi pemerintah untuk meningkatkan porsi anggaran APBN untuk program pemberdayaan masyarakat. Selain itu, dengan gambaran diatas, kita juga patut optimis bahwa dengan 


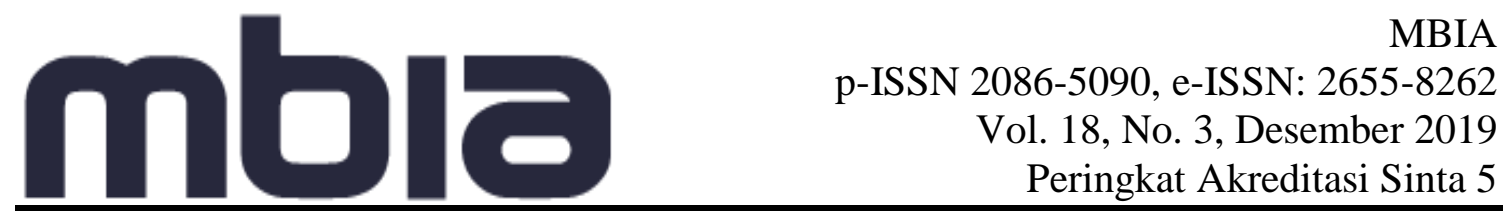

tingkat pertumbuhan ekonomi yang ada, juga dibarengi dengan pergeseran pemerataan hasil pembangunan yang di tahun-tahun lalu menunjukkan jurang ketidakadilan yang luar biasa.

\section{Metodologi Penelitian}

Penelitian ini dilakukan mulai April sampai Juli 2019. Lokasi penelitian adalah wilayah kecamatan Tugumluyo Kabupaten Musi Rawas. Dalam penelitian ini digunakan metode kualitatif agar diketahui peranan UMKM dalam mengatasi kemiskinanserta pendekatan yang akan dilakukan agar tercipta sinergi antara UMKM dan masyarakat dalam upaya pengentasan kemiskinan. Cara kerja adalah melakukan penetapan wilayah studi dan sampel, metode pengumpuland ata dan metode analisis data.

Adapun lokasi yang akan dipilih sebanyak 4 lokasi yaitu Desa tertinggal yaitu Desa Dwijaya, Nawangsasi, Wonokererto dan Wukir Sari. Data yang digunakan dalam penelitian ini menggunakan data primer dan sekunder. Data primer yang diperoleh melalui observasi dan wawancara dengan pihak terkait sedangkan data sekunder berupa dokumen dan buku buku yang relevan, publikasi institusi, artikel populer yang sebagian diperoleh secara online. Metode analisis data yang digunakan dalam penelitian ini adalah analisis deskriptif sifatnya berupa narasi yang menjabarkan tafsir data tentang nilai suatu variabel ketika dihubungkan dengan tahun-tahun yang berbeda.

Untuk pemberdayaan UMKM menggunakan data aliran dana Kredit Usaha Kecil (KUR) ke Musi Rawas selama 5 tahun terakhir. Sedangkan untuk melihat tingkat kemiskinan pada rumah tangga pembudidaya diukur melalui pendekatan karakteristik kemiskinan dengan menggunakan 14 indikator yang dikembangkan oleh Badan Pusat Statistik (BPS). Keempat belas indikator tersebut adalah luasan rumah, jenis lantai, jenis dinding, fasilitas toilet, sumber penerangan, sumber air minum, jenis bahan bakar, konsumsi daging, susu, ayam, ikan, belanja pakaian, frekuensi makan perhari, kemampuan berobat, pendapatan rumah tangga, pendidikan kepala keluarga dan tabungan / kepemilikan barang berharga.

\section{Hasil dan Pembahasan}

\section{Gambaran Umum UMKM Di Kecamatan Tugumulyo}

Sektor Usaha Kecil Menengah (UKM) jika dapat dikelola dengan baik tentu menjadi keuntungan yang sangat besar untuk pertumbuhan ekonomi di daerah maupun nasional.Sektor ini merupakan salah satu penyumbang terbesar Nilai Produk Domestik Bruto (PDB) negara dan juga solusi efektif permasalahan ekonomi bagi seluruh masyarakat kelas kecil dan menengah.

Tabel. 4.1 Hasil Observasi tentang ciri khas masing-masing Desa

\begin{tabular}{|c|c|c|c|c|c|}
\hline No & Desa & $\begin{array}{l}\text { Luas } \\
\text { Lahan } \\
(\mathrm{Ha})\end{array}$ & $\sum_{\text {(Jiwa) }}$ Penduduk & $\begin{array}{l}\sum_{\text {Petani }} \text { KK } \\
\text { (Jiwa) }\end{array}$ & Ciri Khas UKM Desa \\
\hline 1. & Tegal Rejo & 3392 & 809 & 327 & $\begin{array}{ll}\text { - } & \text { Ada pengrajin Batu } \\
\text { Bata } & \\
\text { - } & \text { Usaha keripik } \\
\text { tempe } & \end{array}$ \\
\hline
\end{tabular}


MBIA
p-ISSN 2086-5090, e-ISSN: 2655-8262
Vol. 18, No. 3, Desember 2019
Peringkat Akreditasi Sinta 5

\begin{tabular}{|c|c|c|c|c|c|}
\hline 2. & Widodo & 4398 & 1023 & 420 & Pengrajin Batu Bata \\
\hline 3. & Surodadi & 2174 & 678 & 603 & $\begin{array}{l}\text { - Usaha kerupuk ubi } \\
\text { - Usaha tape }\end{array}$ \\
\hline 4. & Srikaton & 4850 & 1351 & 496 & $\begin{array}{ll}- & \text { Usaha tahu } \\
\text { - } & \text { Usaha Meubel }\end{array}$ \\
\hline 5. & Kali Bening & 1469 & 428 & 289 & $\begin{array}{ll}\text { - } & \text { Usaha makanan } \\
& \text { klanting } \\
\text { - } & \text { Usaha Tahu } \\
\text { - } & \text { Usaha kerupuk }\end{array}$ \\
\hline 6. & Trikoyo & 4386 & 778 & 286 & Budidaya Jamur tiram \\
\hline 7. & Nawangsasi & 1980 & 605 & 462 & $\begin{array}{ll}\text { - } & \text { Usaha kerupuk } \\
& \text { jengkol } \\
\text { - } & \text { Usaha tahu } \\
\text { - } & \text { Usaha tempe }\end{array}$ \\
\hline 8. & Sukomulyo & 865 & 267 & 265 & $\begin{array}{ll}\text { - } & \text { Pengrajin batu bata } \\
\text { - } & \text { Usaha keripik salai } \\
\text { pisang } & \\
\text { - } & \text { Usaha keripik } \\
\text { tempe } & \end{array}$ \\
\hline 9. & Wonokerto & 2518 & 659 & 631 & $\begin{array}{ll}\text { - } & \text { Pengrajin batu bata } \\
\text { - } & \text { Usaha keripik } \\
\text { tempe }\end{array}$ \\
\hline 10. & Wukir Sari & 2047 & 602 & 410 & Pengrajin batu bata \\
\hline 11. & Mataram & 4019 & 1038 & 982 & $\begin{array}{ll}\text { - } & \text { Usaha kerupuk } \\
\text { - } & \text { Usaha kue } \\
\text { - } & \text { Usaha bengkel las }\end{array}$ \\
\hline 12. & Ngadirejo & 1351 & 405 & 672 & $\begin{array}{lll}\text { - } & \text { Budidaya } \\
& \text { Ikan Lele }\end{array}$ \\
\hline 13. & Sidoharjo & 3141 & 995 & 758 & $\begin{array}{ll}\text { - } & \text { Usaha klanting } \\
\text { - } & \text { Usaha anyaman } \\
& \text { rotan } \\
\text { - } & \text { Usaha bengkel las }\end{array}$ \\
\hline 14. & $\begin{array}{l}\text { Tambah } \\
\text { Asri }\end{array}$ & 2938 & 915 & 558 & - $\begin{array}{l}\text { Usaha keripik } \\
\text { tempe }\end{array}$ \\
\hline 15. & Wonorejo & 1355 & 416 & 603 & - Usaha tempe \\
\hline 16. & Dwijaya & 2971 & 954 & 1513 & $\begin{array}{ll}\text { - } & \text { Usaha kerupuk } \\
& \text { rengginang } \\
\text { - } & \text { Pengrajin batu bata } \\
\text { - } & \text { Usaha tahu } \\
\text { - } & \text { Usaha meubel }\end{array}$ \\
\hline 17. & Siti Harjo & 1860 & 558 & 396 & $\begin{array}{ll}\text { - Usaha marning } \\
\text { jagung } \\
\text { - Usaha aneka roti } \\
\text { dan kue }\end{array}$ \\
\hline
\end{tabular}




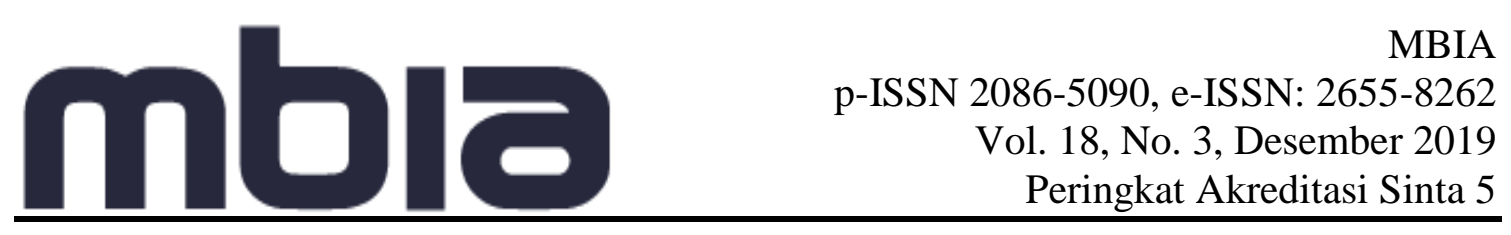

\begin{tabular}{|c|c|c|c|c|c|}
\hline & & & & & $\begin{array}{ll}\text { - } & \text { Usaha keripik ubi } \\
\text { - } & \text { Usaha kerupuk ubi } \\
\text { - } & \text { Pengrajin batu bata }\end{array}$ \\
\hline 18. & Triwikaton & 2547 & 600 & 137 & $\begin{array}{ll}\text { - } & \text { Usaha kerupuk } \\
& \text { kemplang } \\
\text { - } & \text { Usaha siomay } \\
\text { - } & \text { Usaha kue-kue } \\
& \text { kering } \\
\end{array}$ \\
\hline
\end{tabular}

Berdasarkan hasil wawancara dengan perangkat di masing - masing desa yang ada di Kecamatan Tugumulyo bahwa di masing-masing desa terutama di 4 (empat) desa tertinggal sudah ada Usaha Mikro Kecil Menengah yang dikelola oleh perorangan atau pun juga merupakan usaha kelompok masyarakat.

\section{Permasalahan UMKM}

Sektor Usaha Kecil Menengah (UKM) jika dapat dikelola dengan baik tentu menjadi keuntungan yang sangat besar untuk pertumbuhan ekonomi di daerah maupun nasional. Sektor ini merupakan salah satu penyumbang terbesar Nilai Produk Domestik Bruto (PDB) negara dan juga solusi efektif permasalahan ekonomi bagi seluruh masyarakat kelas kecil dan menengah.

Permasalahan UMKM yang ditemukan di lokasi penelitian tidak berbeda dengan masalah-masalah yang telah diungkapkan oleh studi-studi sebelumnya Menurut [3] yaitu masalah permodalan, dan manajemen. Begitupun permasalahan dalam pemberdayaan UMKM di kecamatan Tugumulyo ini adalah masalah kekurangan modal, namun UMKM enggan untuk datang ke bank khususnya karena terkait oleh banyaknya persyaratan yang diperlukan untuk memperoleh fasilitasi kredit dari perbankan. Sebaliknya sering lembaga keuangan menghadapi masalah bagaimana memasarkan "modal" yang dihimpun dari masyarakat tersebut agar dapat tersalur kepada pengusaha UMKM dengan aman. Artinya ke dua belah pihak sebenarnya dapat membentuk hubungan yang saling menguntungkan. Untuk itu perlu diupayakan pendekatan baru perbankkan terhadap UMKM, salah satunya dengan pendekatan melalui kelompok simpan pinjam (KSM) maupun kelompok usaha (koperasi) dalam memberikan layanan kredit terhadap UMKM.

Berlimpahnya sumber daya alam di Kabupaten Musi Rawas terutama di Kecamatan Tugumulyo tidak mampu dikelola dengan baik oleh karena kapasitas dan kapabilitas sumber daya manusia. Sebagai konsekuensinya, muncul fenomena sosial di masyarakat yang tak kunjung selesai, yaitu permasalahan kemiskinan. Dengan bertitik tolak pada diberlakukannya otonomi daerah, wewenang pengembangan daerah dapat dilaksanakan oleh pemerintah daerah secara maksimal. Walaupun pemerintah daerah telah berupaya keras dalam penanggulangan kemiskinan di daerahnya. Namun demikian, dalam prakteknya upaya ini dirasakan tidak maksimal. Secara kuantitas, angka kemiskinan tidak mengalami penurunan yang signifikan.

Sebagai usaha yang memiliki keterbatasan dalam sumber daya, UMKM mengalami berbagai permasalahan mendasar. Permasalahan ini merupakan permasalahan umum di setiap wilayah, permasalahan dan keterbatatan UMKM, antara lain kurangnya modal, 
informasi bisnis, teknologi, tenaga ahli, kesulitan dalam pengadaan barang, pemasaran dan distribusi, serta aturan dan kebijakan pemerintah. Untuk menjamin adanya pertumbuhan UMKM, pemerintah memiliki berbagai program dan kebijakan yang memadai. Secara penyerapan tenaga kerja, UMKM di kecamatan Tugumulyo menjadi tumpuan dalam menjaga dan mengurangi angka pengangguran. Bila UMKM tidak dapat bertahan dalam persaingan bisnis, akan berdampak pada banyaknya tenaga kerja yang kehilangan pekerjaannya. Dampak jangka panjangnya adalah tingginya angka kemiskinan di daerah tersebut. Begitu mudah ditemui orang yang masih hidup di bawah standar yang layak. Di sisi lain, UMKM yang ada di daerah masih belum dikelola dengan baik. Hal ini dapat dilihat dari sangat sedikitnya produk UMKM unggulan yang mampu bersaing di pasar lokal, terlebih di pasar internasional. Hal ini mengindikasikan belum maksimalnya pemberdayaan UMKM di daerah. Untuk itu perlu ada usaha dari pemerintah untuk menahan laju pertumbuhan penduduk miskin.

\section{Indikator Kemiskinan}

Dalam menentukan rumah tangga miskin, BPS menggunakan 14 variabel sesuai dengan peneliti terdahulu [2], untuk menentukan apakah suatu rumah tangga layak dikategorikan miskin. Keempat belas variabel tersebut adalah: luas bangunan, jenis lantai, jenis dinding, fasilitas buang air besar, sumber air minum, sumber penerangan, jenis bahan bakar untuk memasak; frekuensi membeli daging, ayam, dan susu dalam seminggu, frekuensi makan dalam sehari, jumlah stel pakaian baru yang dibeli dalam setahun, akses ke puskesmas/poliklinik, akses ke lapangan pekerjaan, pendidikan terakhir kepala rumah tangga, dan kepemilikan beberapa aset.

Berdasarkan hasil observasi dan wawancara dengan sekretaris desa pada 4 desa tertinggal di kecamatan Tugumulyo yaitu Desa Wonokerto, Desa Dwijaya, Desa Nawangsasi, dan Desa Wukir Sari bahwa berdasarkan penilaian dari Badan Pusat statistik dan juga dari Dinas Pemberdayaan Masyarakat Desa untuk masing-masing desa dikategorikan sebagai desa tertinggal dikarenakan sebagian besar rumah warga desa itu tidak memiliki jamban hal ini menyulitkan mereka dalam buang air, kemudian juga rumah warga yang memiliki jenis lantai dan dinding yang tidak layak huni. Hasil wawancara dengan 12 kepala keluarga di masing-masing desa tertinggal menghasilkan kriteria keluarga sejahtera 1, pra sejahtera dan miskin.

Tabel 4. 3. Kriteria Keluarga sejahtera 1, pra sejahtera dan miskin di kecamatan Tugumulyo

\begin{tabular}{|l|l|l|l|l|}
\hline No. & Komponen & Sejahtera & Pra Sejahtera & Miskin \\
\hline 1. & Rumah & $\begin{array}{l}\text { Dinding tembok } \\
\text { kualitas bagus, } \\
\text { lantai keramik }\end{array}$ & $\begin{array}{l}\text { Dinding kayu/kualitas } \\
\text { rendah, lantai keramik } \\
\text { atau diplester }\end{array}$ & $\begin{array}{l}\text { Dinding kayu, } \\
\text { lantai dari tanah }\end{array}$ \\
\hline 2. & Luas Rumah & $\begin{array}{l}\text { Luas rumah >=15 } \\
\text { m2/jiwa, sudah ada } \\
\text { pembagian ruang }\end{array}$ & $\begin{array}{l}\text { Luas rumah <=15 } \\
\text { m2/jiwa,belum ada } \\
\text { pembagian ruangan }\end{array}$ & $\begin{array}{l}\text { Luas rumah <=6 } \\
\text { m2/jiwa,belum ada } \\
\text { pembagian ruangan }\end{array}$ \\
\hline 3. & MCK & $\begin{array}{l}\text { Punya MCK } \\
\text { sendiri }\end{array}$ & $\begin{array}{l}\text { Sungai, tidak punya } \\
\text { MCK di } \\
\text { rumah }\end{array}$ & $\begin{array}{l}\text { Sungai, tidak } \\
\text { punya MCK di } \\
\text { rumah }\end{array}$ \\
\hline
\end{tabular}




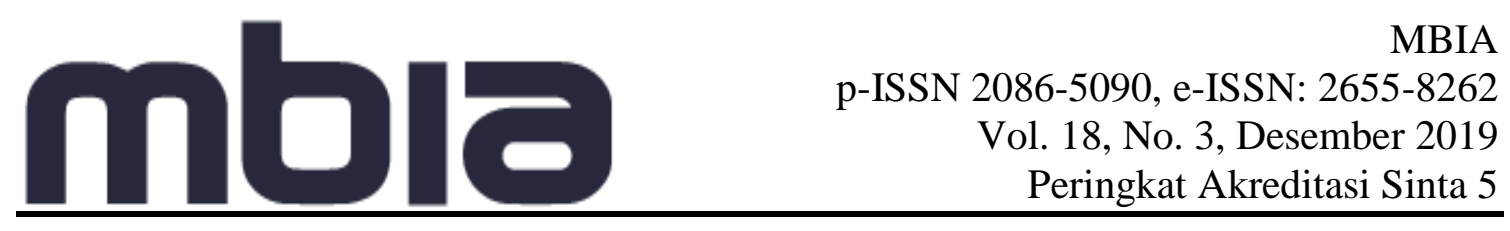

\begin{tabular}{|l|l|l|l|l|}
\hline 4. & $\begin{array}{l}\text { Sumber Air } \\
\text { bersih }\end{array}$ & $\begin{array}{l}\text { Sudah ada } \\
\text { pompa/ada } \\
\text { sumber mata air/air } \\
\text { pam }\end{array}$ & $\begin{array}{l}\text { Sudah ada pompa/ada } \\
\text { sumber mata air/air } \\
\text { pam }\end{array}$ & $\begin{array}{l}\text { Numpang tetangga, } \\
\text { dari } \\
\text { sungai kalo } \\
\text { kemarau, tak ada } \\
\text { sumber mata air }\end{array}$ \\
\hline 5. & $\begin{array}{l}\text { Mata } \\
\text { Pencaharian/ } \\
\text { Pekerjaan }\end{array}$ & $\begin{array}{l}\text { Punya pekerjaan } \\
\text { tetap }\end{array}$ & $\begin{array}{l}\text { Tidak menentu, tidak } \\
\text { tetap, } \\
\text { serabutan }\end{array}$ & $\begin{array}{l}\text { Tidak punya } \\
\text { pekerjaan tetap, } \\
\text { tenaga fisik kurang, } \\
\text { bantuan } \\
\text { dari orang lain }\end{array}$ \\
\hline 6. & Penghasilan & $\begin{array}{l}\text { Cukup untuk hidup } \\
\text { sehari-hari, } \\
>\text { Rp.100.000/ } \\
\text { jiwa/hari }\end{array}$ & $\begin{array}{l}\text { Cukup untuk hidup } \\
\text { sehari-hari, } \\
\text { >Rp.50.000/ } \\
\text { jiwa/hari }\end{array}$ & $\begin{array}{l}\text { Tidak punya } \\
\text { penghasilan tetap }\end{array}$ \\
\hline 7. & $\begin{array}{l}\text { Pendidikan } \\
\text { anak }\end{array}$ & $\begin{array}{l}\text { Tamat SMA, } \\
\text { Sarjana }\end{array}$ & $\begin{array}{l}\text { Tamat SMA dan ada } \\
\text { juga Sarjana }\end{array}$ & Tamat SMA \\
\hline 8. & Kesehatan & Berobat ke Dokter & Berobat ke Puskesmas & $\begin{array}{l}\text { Berobat ke } \\
\text { Puskesmas gratis }\end{array}$ \\
\hline
\end{tabular}

Sumber : hasil penelitian

\section{Permasalahan Kemiskinan}

Kemiskinan sesungguhnya merupakan masalah multidimensi dimana dalam strategis kemiskinan disebutkan bahwa dimensi kemiskinan mencakup kurangnya kesempatan, kurangnya kemampuan, kurangnya jaminan dan ketidakberdayaan. Menurut [8] ada umumnya kemiskinan selalu dikaitkan dengan tingkat pendapatan yang bisa dibedakan menjadi kemiskinan absolut dan kemiskinan relatif. Kemiskinan absolut adalah jika penghasilan tidak mampu memenuhi kebutuhan dasar baik berupa makanan maupun non makanan. Sedangkan kemiskinan relatif menunjukkan tingkat ketimpangan dalam distribusi atau pembagian pendapatan diantara berbagai golongan penduduk, antar daerah maupun antar sektor kegiatan ekonomi.

Menurut [8], penyebab kemiskinan dapat dibedakan menjadi tiga kategori yaitu kemiskinan natural, struktural dan kultural. Kemiskinan natural adalah keadaan kemiskinan karena dari asalnya memang sudah miskin. Kelompok masyarakat ini miskin karena tidak memiliki sumber daya yang memadai baik sumber daya alam maupun sumber daya manusia sehingga mereka tidak dapat ikut serta secara aktif dalam pembangunan. Kemiskinan struktural adalah penduduk miskin selain tidak bisa mencukupi pangan dan sandang juga karena tidak sanggup mendapatkan pendidikan dan pelayanan kesehatan yang memadai serta terkucil dalam pergaulan sosial di lingkungannya atau kemiskinan yang timbul karena adanya ketidakadilan dalam kepemilikan faktor produksi, kemiskinan terkait dengan sikap, budaya hidup dan lingkungan mencari nafkah yang terbatas atau ketidakberdayaan terhadap sistem yang diterapkan oleh suatu pemerintah sehingga kelompok masyarakat ini berada pada posisi yang sangat lemah dan tereksploitasi. Kemiskinan struktural dalam banyak hal terjadi bukan karena seorang individu atau anggota keluarga malas bekerja atau karena mereka terus menerus sakit. Berbeda dengan perspektif modernisasi yang cendrung memvonis 


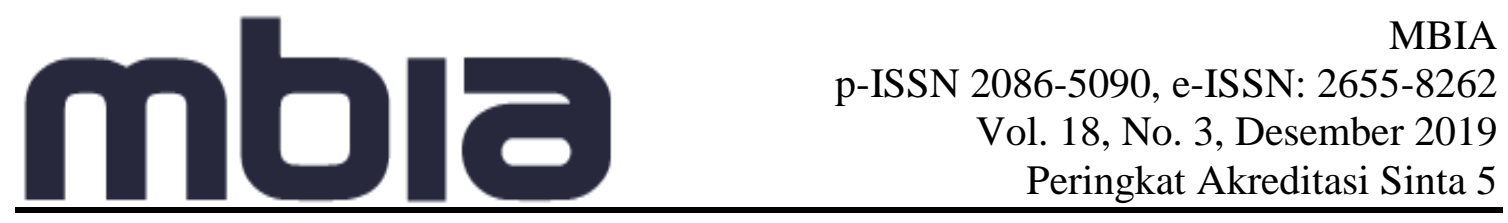

kemiskinan bersumber dari lemahnya etos kerja, tidah dimilikinya etika wirausaha atau karena budaya yang tidak terbiasa dengan kerja keras. Sementara itu kemiskinan kultural mengacu kepada sikap seseorang atau masyarakat karena gaya hidup, kebiasaan dan budaya. Meraka merasa sudah berkecukupan dan sama sekali tidak merasa kekurangan. Kelompok masyarakat ini sangat sulit untuk melakukan perubahan, menolak untuk mangikuti perkembangan dan tidak mau berusaha untuk memperbaiki tingkat hidupnya.

Kemiskinan merupakan permasalahan sosial yang memiliki pengaruh terhadap berbagai permasalahan di masyarakat seperti kriminalitas, perceraian dan lain-lain, Hasil wawancara awal dengan Kasi Kesos Kecamatan Tugumulyo pada tahun 2018, Ibu Nurbaiti, S.E bahwa pada wilayah Kecamatan Tugumulyo terdapat 4 (empat) Desa yang terkategori sebagai Desa tertinggal yaitu Desa Dwijaya, Nawangsasi, Wonokererto dan Wukir Sari.

Hasil penelitian dilakukan di 4 desa tertinggal dikecamatan Tugumulyo ini dengan menggunakan responden dari kategori keluarga Sejahtera 1, Prasejahtera dan Miskin. Untuk keluarga yang termasuk kategori Sejahtera 1 adalah keluarga disamping telah dapat memenuhi kebutuhan dasarnya (sandang, pangan dan papan) juga telah dapat memenuhi kebutuhan pengembangannya seperti kebutuhan untuk menabung dan memperoleh informasi.

Pada keluarga sejahtera 1 ini kebutuhan fisik dan sosial psikologis telah terpenuhi (a s/d $\mathrm{n}$ telah terpenuhi) namun kebutuhan pengembangan belum yaitu:

- Mempunyai upaya untuk meningkatkan agama.

- Sebagian dari penghasilan dapat disisihkan untuk tabungan keluarga.

- Biasanya makan bersama paling kurang sekali sehari dan kesempatan ini dapat dimanfaatkan untuk berkomunikasi antar anggota keluarga.

- Ikut serta dalam kegiatan masyarakat dilingkungan keluarga.

- Mengadakan rekreasi bersama di luar rumah paling kurang 1 kali perbulan.

- Dapat memperoleh berita dan surat kabar, radio, televisi atau majalah.

- Anggota keluarga mampu menggunakan sarana trasportasi sesuai kondisi daerah.

Untuk keluarga yang termasuk kategori pra sejahtera adalah keluarga yang karena alasan ekonomi tidak dapat memenuhi salah satu atau lebih indikator, meliputi :

- Indikator ekonomi :

Paling kurang sekali seminggu keluarga makan daging atau ikan atau telor, Setahun terakhir seluruh anggota keluarga memperoleh paling kurang satu stel pakaian baru, keadaan rumah tinggal keluarga mempunyai atap, lantai dan dinding dalam kondisi yang layak ditempati, baik dari segi perlindungan maupun dari segi kesehatan.

- Indikator non ekonomi :

Bila ada anggota keluarga sakit di bawa ke prasarana kesehatan (maksudnya adalah sarana kesehatan modern, seperti Rumah Sakit, Puskesmas, Puskesmas Pembantu, Balai Pengobatan, Apotek, Posyandu, Poliklinik, Bidan Desa dan sebagainya, yang memberikan obat-obatan yang diproduksi secara modern dan telah mendapat izin peredaran dari instansi yang berwenang (Departemen Kesehatan/Badan POM), Ibadah teratur, sehat tiga bulan terakhir, punya penghasilan tetap, usia 10-60 tahun dapat baca tulis huruf, usia 6-15 tahun bersekolah. 
Untuk keluarga yang termasuk kategori Miskin adalah keluarga yang belum dapat memenuhi kebutuhan dasarnya (basic need) secara minimal, seperti kebutuhan akan spiritual, pangan, sandang, papan, kesehatan.

- Melaksanakan ibadah menurut agama oleh masing-masing anggota keluarga

- Pada umunya seluruh anggota keluarga, makan dua kali atau lebih dalam sehari

- Seluruh anggota keluarga mempunyai pakaian berbeda di rumah, bekerja, sekolah atau berpergian.

- Bagian yang terluas dari lantai bukan dari tanah.

- Bila ada anggota keluarga yang sakit berobat ke Puskesmas

- Aspek sosial : motivasi hidup rendah, pasrah terhadap keadaan, tidak memiliki inisiatif, banyak keinginan tapi tidak ada usaha, terlalu terikat dengan tradisi

Selanjutnya dari hasil observasi ke 4 (empat) Desa tersebut diketahui mayoritas penduduk di Desa tersebut bermata pencaharian sebagai petani padi dan karet, secara rinci hasil observasi di empat Desa tersebut dijelaskan sebagai berikut :

\section{a). Desa Wonokerto}

Wonokerto merupakan salah satu dari 4 (empat) Desa yang dikategorikan miskin dan tertinggal, dengan mayoritas mata pencaharian penduduk sebagai petani karet, mengingat harga karet yang merupakan komoditi ekspor yang harganya berfluktuasi tergantung keadaan perekonomian dunia, seperti yang terjadi saat ini harga karet jatuh, sedangkan mayoritas mata pencaharian warga masyarakat sebagai petani karet, maka akan berdampak pada pendapatan yang diterima, artinya saat harga turun, maka pendapatan petani pun akan ikut turun, dan rentan akan terjadi kemiskinan, secara rinci uraian pendapatan sampel penelitian di Desa Wonokerto dapat dilihat pada Tabel 1 berikut.

Tabel 4.1. Pendapatan Penduduk Desa Wonokerto

\begin{tabular}{clc}
\hline \hline No & \multicolumn{1}{c}{ Kategori } & $\begin{array}{c}\text { Rata-Rata } \\
\text { Pendapatan }\end{array}$ \\
\hline \hline 1. & Sejahtera 1 & 8.037 .000 \\
2. & Pra Sejahtera & 6.493333 \\
3. & Miskin & 2.166 .083 \\
\hline \hline
\end{tabular}

Berdasarkan Tabel di atas terlihat bahwa untuk pendapatan penduduk miskin di Desa Wonokerto sebesar Rp. 2.166 .083 per bulan yang berada di bawah tingkat Upah Minimum Kabupaten (UMK) Kabupaten Musi Rawas Rp. 2.507.400 per bulan, atau bisa disimpulkan penduduk miskin di Desa Wonokerto memiliki pendapatan yang lebih Rendah 80 persen dari UMK Kabupaten Musi Rawas. Dari temuan di lokasi penelitian ini diketahui bahwa kemiskinan ini dikarenakan rendahnya harga karet dalam kurun waktu 5 tahun terakhir ini, sehingga pendapatan yang diterima penduduk Desa turun dan berada di bawah UMK Kabupaten, sementara itu untuk penduduk sejahtera dan pra sejahtera mereka tidak hanya bergantung dari karet melainkan juga dari sumber pendapatan lainnya seperti ataupun mereka memiliki luasan lahan yang lebih besar dari $1,5 \mathrm{Ha}$.

Uraian hasil temuan di lokasi penelitian sejalan dengan informasi yang diperoleh dari bapak Kades yang mengatakan kemiskinan penduduk di Desa ini "disebabkan rendahnya harga karet, sehingga mereka sulit untuk memenuhi kebutuhan hidup mereka, selain itu 
juga disebabkan oleh budaya malas dari masyarakatnya, kesadaran masyarakat itu rendah dalam rangka pengembangan usaha, mereka terbiasa mengandalkan bantuan dari pemerintah, akhirnya manja. Selanjutnya untuk potensi Desa apa yang dimiliki yang dapat membantu perekonomian penduduk di Desa tersebut terutama saat harga karet turun, dari observasi dilokasi penelitian diketahui bahwa Desa Wonokerto memiliki potensi yaitu industri batu bata.

\section{b). Desa Dwijaya}

Di Desa Dwijaya ini mayoritas penduduknya juga bermata pencaharian sebagai petani karet, adapun rata-rata pendapatan responden penelitian berdasarkan kategorinya dapat dilihat secara rinci pada Tabel 4.2 berikut.

\section{Tabel 4.2. Pendapatan Penduduk Desa Dwijaya}

\begin{tabular}{clc}
\hline \hline No & \multicolumn{1}{c}{ Kategori } & $\begin{array}{c}\text { Rata-Rata } \\
\text { Pendapatan }\end{array}$ \\
\hline \hline 1. & Sejahtera 1 & 6.779 .833 \\
2. & Pra Sejahtera & 3.599 .978 \\
3. & Miskin & 1.994 .500 \\
\hline \hline
\end{tabular}

Terlihat bahwa pendapatan penduduk miskin di Desa Dwijaya berada pada tingkat Rp. 1.994.500 per bulan dibawah UMK Kabupaten Musi Rawas, dengan mayoritas sebagai petani karet otomatis rendahnya pendapatan ini diringi oleh rendahnya harga karet. Informasi yang diperoleh dari bapak Sekdes Dwijaya bahwa kemiskinan di desa ini juga disebabkan oleh gagal pembelanjaan, yaitu masyarakat mayoritas ada pinjaman dibank atau juga bank keliling (dengan bunga yang tinggi).

\section{c). Desa Nawangsasi}

Di Desa Nawangsasi ini mayoritas penduduknya bermata pencaharian sebagai petani padi, adapun rata-rata pendapatan responden penelitian berdasarkan kategorinya dapat dilihat secara rinci pada Tabel 4.3 berikut :

\section{Tabel 4.3. Pendapatan Penduduk Desa Nawangsasi}

\begin{tabular}{clc}
\hline \hline No & \multicolumn{1}{c}{ Kategori } & $\begin{array}{c}\text { Rata-Rata } \\
\text { Pendapatan }\end{array}$ \\
\hline \hline 1. & Sejahtera 1 & 9.054 .458 \\
2. & Pra Sejahtera & 4.004 .167 \\
3. & Miskin & 2.088 .917 \\
\hline \hline
\end{tabular}

- Berdasarkan Tabel di atas terlihat bahwa untuk pendapatan penduduk miskin di Desa Nawangsasi sebesar Rp. 2.088.917 per bulan yang berada di bawah tingkat Upah Minimum Kabupaten (UMK) Kabupaten Musi Rawas Rp. 2.507 .400 per bulan. Dari temuan di lokasi penelitian ini diketahui bahwa kemiskinan ini dikarenakan Kemiskinan konjungtural (gagal panen) : Untuk desa ini pernah terjadi gagal panen, hal ini disebabkan karena lahan sawah kering lantaran kesulitan mendapatkan pasokan air, akibatnya produksi menurun, selain itu juga gagal panen disebabkan oleh hama wereng/tikus dan juga diiringi gagal pembelanjaan : hampir sebagian besar 


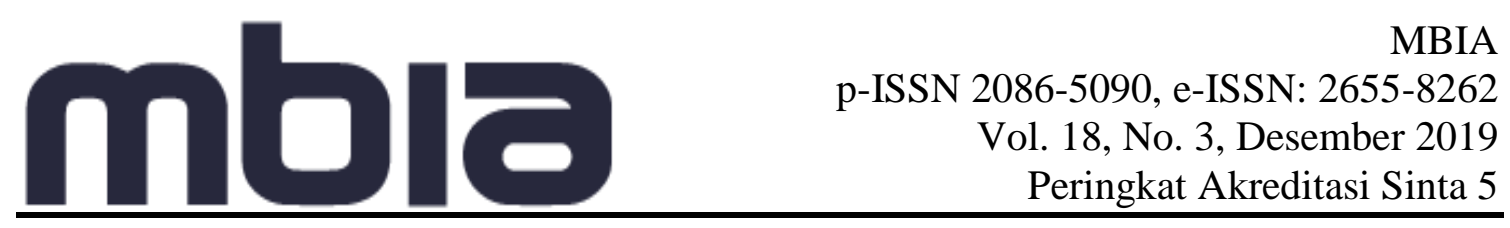

masyarakat mempunyai pinjaman pada bank BRI, bank keliling (dengan bunga yang lebih tinggi).

\section{d). Desa Wukir Sari}

Di Desa Wukir Sari ini mayoritas penduduknya juga bermata pencaharian sebagai petani padi, adapun rata-rata pendapatan responden penelitian berdasarkan kategorinya dapat dilihat secara rinci pada Tabel 4.4 berikut.

Tabel 4.4 Pendapatan Penduduk Desa Wukir Sari

\begin{tabular}{clc}
\hline \hline No & \multicolumn{1}{c}{ Kategori } & $\begin{array}{c}\text { Rata-Rata } \\
\text { Pendapatan }\end{array}$ \\
\hline \hline 1. & Sejahtera 1 & 6.475 .000 \\
2. & Pra Sejahtera & 3.522 .500 \\
3. & Miskin & 2.116 .667 \\
\hline \hline
\end{tabular}

Terlihat bahwa pendapatan penduduk miskin di Desa Wukir Sari berada pada tingkat Rp. 2.116.667 per bulan dibawah UMK Kabupaten Musi Rawas, dengan mayoritas sebagai petani, di desa ini pada musim pernah terjadi gagal panen, hal ini disebabkan karena serangan hama wereng dan tikus.

\section{Upaya Pengentasan Kemiskinan Melalui Pemberdayaan UMKM}

a. Pengentasan kemiskinan dengan cara mengembangkan UMKM

UMKM memiliki potensi yang cukup baik. Sektor UMKM memiliki kontribusi yang besar bagi penyerapan tenaga kerja, yaitu menyerap lebih dari $85 \%$ tenaga kerja. Upaya untuk memajukan sektor UMKM tentu saja akan dapat meningkatkan kesejahteraan para pekerja yang terlibat di dalamnya. Pengembangan UMKM akan dapat menyerap lebih banyak lagi tenaga kerja yang ada sehingga dapat mengurangi angka pengangguran.

Sebenarnya yang menyebabkan terjadinya kemiskinan adalah masyarakat yang memang dalam kondisi miskin, yaitu miskin sumber daya, miskin produktivitas, miskin pendapatan, miskin tabungan dan miskin investasi. Dengan investasi produktif, diharapkan dapat mendorong pertumbuhan ekonomi, membuka lapangan pekerjaan, meningkatkan pendapatan masyarakat, dan meningkatkan kualitas sumber daya manusia.

Upaya penggelontoran kredit mikro bagi usaha kecil dan mikro yang dilakukan pemerintah ini sebenarnya merupakan bagian dari upaya untuk mengentaskan kemiskinan. Dana penyediaan kredit mikro ini diperoleh dari sebagian dana kompensasi BBM. Besar sekali harapan akan keberhasilan program ini, mengingat tumbuhnya UMKM yang menyerap mayoritas tenaga kerja di dikecamatan Tugumulyo diyakini akan memberikan dampak yang signifikan bagi upaya pengentasan kemiskinan.

Banyak program yang telah dijanjikan pemerintah untuk menyalurkan dana kompensasi BBM tersebut mulai dari pemberian bantuan pendidikan, kesehatan sampai pemberian kredit mikro bagi Usaha Mikro Kecil dan Menengah (UMKM). Pencanangan sebuah program dalam upaya mengembangkan UMKM bukanlah hal yang baru. Telah banyak program yang dibuat namun kurang memberikan dampak yang signifikan. Untuk itu perlu 
kiranya kita melihat kembali dan apa yang perlu dilakukan untuk menunjang keberhasilan program ini.

\section{b. Pengembangan Secara Internal dari Kelompok UMKM di Kecamatan Tugumulyo}

Adapun potensi dan pengembangan yang dilakukan oleh UMKM terdiri dari:

(1) Pengadaan permodalan

Modal adalah faktor terpenting dalam membuka usaha. Karena UMKM merupakan usaha rumahan yang mengandalkan modal sendiri, maka dalam permodalan ini memerlukan bantuan dari pemerintah. Pengelola UMKM terkadang juga terjebak terjebak dengan keterikatan rentenir mengingat masih rendahnya aksesbilitas terhadap sumber-sumber pembiayaan formal. Mengenai pemberian akses terhadap sumber-sumber pendanaan, Dinas Koperasi dan UKM Kabupaten Musi Rawas telah memberikan akses bagi masyarakat terhadap modal awal. Kucuran dana yang diberikan bersumber dari pemerintah pusat. Dari pemerintah pusat bantuan diberikan melalui LPDB (Lembaga Pengelola Dana Bergulir). Dana tersebut di-bagikan kepada koperasi bagi para pengusaha UMKM yang akan melakukan pinjaman modal. Berdasarkan informasi yang diperoleh dari Dinas Koperasi dan Usaha Kecil Menengah (Diskop-UKM) Kabupaten Musi Rawas melalui Kabid Bidang Lembaga Koperasi, Bapak Junaidi mengatakan pihaknya telah menerima pengusulan pendirian lima koperasi wanita yang terdapat di lima kecamatan yakni di Tugumulyo, Purwodadi, Muara Kelingi, Jayaloka, dan BTS Ulu Cecar. Menurutnya, informasi yang diterima untuk usulan lima koperasi wanita yang sudah pernah didirikan dilakukan penelusuran lebih lanjut. Sebab, Diskop-UKM hanya memfasilitasi usulan yang diterima dan tetap dilakukan pengecekan karena ada persyaratan yang harus dipenuhi untuk pendirian koperasi. Syarat pendirian koperasi yakni harus memiliki badan hukum yang diawali dengan data dasar seperti data anggota, anggaran dasar/anggaran rumah tangga (AD/ART), dan susunan pengurus serta data lainnya. Setelah data lengkap diajukan ke notaris untuk dibuatkan akta pendirian. Lalu diusulkan ke Kementerian Koperasi untuk proses pengesahan. Bapak Junaidi menjelaskan dengan didirikannya koperasi diharapkan para pengurus serta anggota mampu mengelola dengan baik sehingga memberikan manfaat besar bagi anggota dan masyarakat. Koperasi juga bisa menjadi sarana menumbuhkembangkan usaha ekonomi kerakyatan di wilayah tersebut. Salah satunya produk unggulan UKM di wilayah kecamatan tersebut. Hingga akhir tahun 2018 tercatat ada 692 koperasi di Kabupaten Mura. Namun, yang aktif sebanyak 555 koperasi sedangkan 137 lainnya tidak aktif. Sinergi antara pemerintah dengan koperasi dilakukan agar para pengusaha UMKM sadar akan pentingnya berkoperasi.

\section{(2) Inovasi hasil produksi}

Produk yang memiliki kualitas yang tinggi akan meningkatkan harga pasar sehingga mampu bersaing dengan produk lain dari luar kecamatan Tugumulyo. Produk dengan kualitas yang baik dan unik biasanya akan menarik minat pembeli, terutama dari luar Tugumulyo. Diharapkan produk yang memiliki kualitas yang baik dipasarkan dengan menggunakan bantuan digital sehingga proses pemasarannya yang mudah dan cepat. Sehingga dalam hal ini produk tidak lagi dipasarkan di pasar domestik namun juga dipasar Internasional dengan kuantitas penjualan yang terus meningkat. 


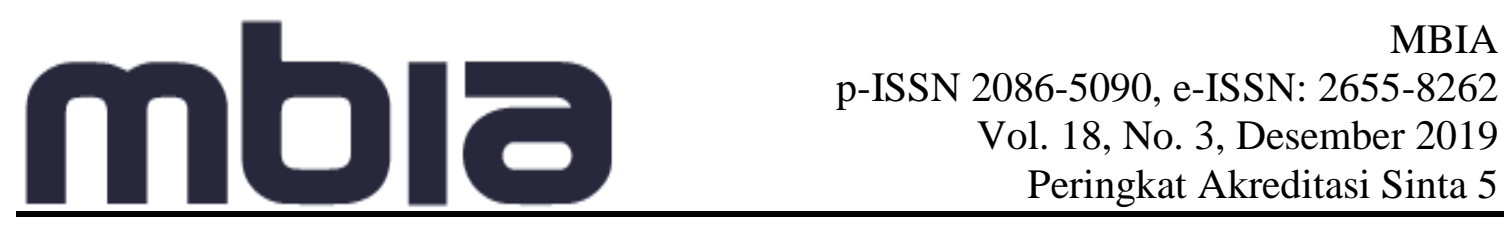

(3) Perluasan jaringan pemasaran

Pengadaan Pembinaan dan pelatihan yang dilakukan oleh Dinas Koperasi dan UKM Kabupaten Musi Rawas merupakan wujud pemberdayaan sebagai motivasi atau dorongan bagi masyarakat untuk lebih mengembangkan kemampuan yang mereka miliki serta dapat menjadikan bekal ilmu pengetahuan dan keterampilan bagi masyarakat yang ingin membuka usaha sendiri. Salah satu cara untuk mengenalkan potensi UMKM di Kecamatan Tugumulyo adalah dengan melakukan pemasaran melalui digital. Ada banyak cara untuk melakukan digital marketing, salah satunya menggunakan sosial media seperti facebook, instagram, yotube dan sosial media lain yang menggunakan jasa iklan. Menyambut revolusi digital, pemilik usaha kecil menengah juga bisa memanfaatkan kemajuan teknologi dengan biaya terjangkau. Sebagian besar aplikasi yang tersedia secara gratis sehingga pemilik usaha kecil menengah tidak terbebani secara finansial.

\section{Pengembangan Secara Eksternal dari Pihak Pemerintah}

UMKM merupakan suatu usaha yang potensial bagi perkembangan perekenomian di Indonesia sehingga dalam pelaksanaannya perlu dioptimalkan dan digali kembali potensipotensi yang ada untuk peningkatan pembangunan ekonomi masyarakat. Pengembangan ini tentu saja akan lebih berkembang dengan baik dengan adanya dukungan dari pemerintah dalam memberikan fasilitas-fasilitas yang diperlukan sebagai penunjang pelaksanaan dan kemajuan usaha yang dijalankan agar dapat menghasilkan kualitas produksi yang baik sehingga dapat bersaing dengan pasar nasional.

(1). Pengadaan pembinaan dan pelatihan

Upaya yang dilakukan oleh Dinas Koperasi dan Usaha Kecil dan Menengah kabupaten Musi Rawas meliputi kegiatan sosialisasi dan pembinaan secara langsung ke lapangan atau melalui kegiatan mengundang UMKM yang ada di Kecamatan Tugumulyo. Proses pembinaan (coaching) memusatkan pada pembelajaran berkesinambungan, pertumbuhan dan perubahan, yang membawa hasil dalam pembangunan keterpenuhan kebutuhan sumber daya internal seseorang. Pembinaan mengarahkan secara langsung atau tidak langsung energi dan keinginan karyawan untuk meningkatkan motivasi, mencapai tujuan, dan memaksimalkan potensi. Dengan kata lain,[9]pembinaan merupakan memberdayakan orang dengan memfa- silitasi pembelajaran diri, pertumbuhan diri, dan perbaikan kinerja. Penyelenggaraan kegiatan lain yang dilakukan yaitu melalui fasilitasi UMKM dalam bentuk modal, hal ini berupa bantuan dari pemerintah dan kerjasama dengan perbankan, serta bantuan alat sebagai sarana dan prasarana dalam mengembangkan usaha UMKM.

(2) Perluasan pemasaran produk

Dalam hal ini Dinas Koperasi dan UKM Kabupaten Musi Rawas telah memberikan sarana dalam pemasaran produk yaitu dengan mengadakan kegiatan promosi produk. Dalam hal pemasaran, kegiatan seperti bazar atau pameran untuk hasil produk UMKM juga disediakan oleh Dinas Koperasi dan UKM Kabupaten Musi Rawas yang bekerjasama dengan UMKM yang berada di kota-kota lain. Saat ini dengan kecanggihan teknologi, pemasaran dapat dilakukan menggunakan sistem online. Karena dengan internet jaringan pemasaran bisa dijangkau hingga ke luar negeri. Namun, hal ini kurang dipahami oleh para pengusaha UMKM karena faktor ilmu pengetahuan berbasis $e$-bisnis yang masih rendah. Untuk mengikuti perkembangan jaman, berbagai pelatihan yang 


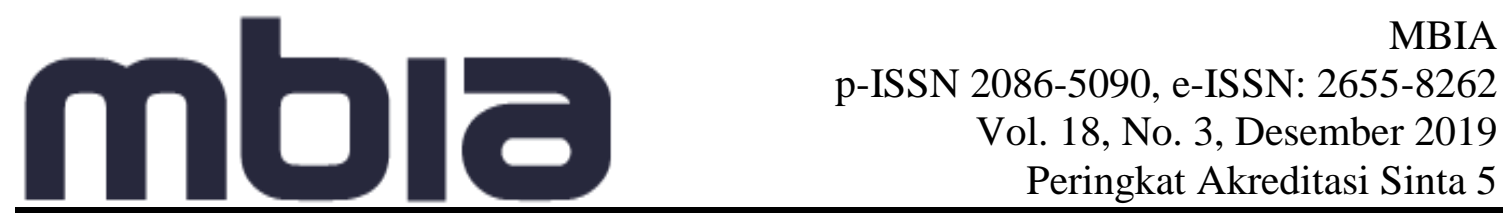

diberikan oleh Dinas Koperasi dan UKM Kabupaten Musi Rawas mengenai IT diikuti oleh para pengelola UMKM. Selanjutnya pemerintah perlu membuat kebijakan terkait pemberdayaan UMKM tersebut. Terdapat tiga hal pokok yang perlu dilakukan sebagai berikut : (1) Pemerintah sebagai regulator dalam kegiatan ekonomi, harus menciptakan lingkungan yang mampu mendorong perkembangan UMKM secara mandiri, sistematik, dan berkelanjutan, (2). Menciptakan guarantee system secara finansial terhadap operasionalisasi aktivitas usaha ekonomi produktif yang dilakukan UMKM, (3). Menyediakan pendampingan dan bantuan teknis secara manajerial untuk meningkatkan status usaha UMKM agar dapat lebih feasible dan bankable.

\section{Simpulan}

Keberhasilan pembangunan perekonomian suatu negara atau pemerintah adalah berkurangnya jumlah penduduk miskin karena pada hakekatnya suatu pembangunan adalah untuk meningkatkan kesejahteraan masyarakat secara adil dan merata. Tujuan pembangunan tersebut erat kaitannya dengan upaya mengurangi kemiskinan dan kesenjangan pendapatan. Salah satu upaya yang dilakukan dalam mengatasi kemiskinan adalah dengan pengembangan ekonomi kerakyatan yang harus diprioritaskan melalui pemberdayaan sektor Usaha Mikro Kecildan Menengah (UMKM). UMKM berperan dalam pertumbuhan ekonomi, penyerapan tenaga kerja dan pendistribusian hasil-hasil pembangunan. Tujuan pokok dari kebijaksanaan pemberdayaan UMKM adalah untuk meningkatkan produktifitas UMKM, mendorong efektifitas program dan kegiatan yang berkaitan denganpemberdayaan UMKM. Pemberdayaan dan pengembangan UMKM merupakan salah satu cara untuk menanggulagi kemiskinan yang terjadi. Caranya adalah memberikan akses kepada penduduk miskin untuk dapat terlibat dalam berusaha dan aktif dalam kegiatan usaha yang produkif dan memasyarakatkan kewirausahaan terutama dikalangan keluarga miskin atau daerah tertinggal. Pengembangan UMKM melalui peningkatan usaha dan keterampilan pengelolaan usaha, akses lembaga keuangan dan sekaligus meningkatkan kepastian dan perlindungan usaha yang mandiri untuk siap tumbuh dan bersaing dengan pelaku ekonomi lainnya. Kecamatan Tugumulyo Kabupaten Musi Rawas memiliki 17 desa dan 1 kelurahan, pada tahun 2018 terdapat 4 Desa Terkategori miskin (tertinggal): Nawangsasi, Wonokerto, Dwijaya dan Wukirsari. Upaya pemberdayaan UMKM dalam rangka mengatasi kemiskinan di kecamatan Tugumulyo yaitu melalui pengembangan secara internal dari pengelola UMKM yaitu pengadaan permodalan, inovasi hasil produk dan perluasan jaringan. Selain itu juga didukung oleh pengembangan secara eksternal dari pihak pemerintah yaitu pengadaan pelatihan dan pembinaan serta perluasan pemasaran produk dengan pendampingan dari Dinas Koperasi dan UKM Kabupaten Musi Rawas. Sebagai sektor utama penyerapan tenaga kerja, kemajuan UMKM akan memberikan dampak yang signifikan bagi peningkatan kesejahteraan masyarakat yang terlibat di dalamnya, sehingga jumlah penduduk miskin akan menurun.

\section{Daftar Pustaka}

Ali Khansan, Arya Hadi Dharmawan, dkk. Indikator Kemiskinan dan Misklasifikasi Orang Miskin. Penerbit Yayasan Pustaka Obor Indonesia.

Anwar Sitepu. (2012). Karakteristik Keluarga Menurut Peringkat Kemiskinan : Studi Pendahuluan Untuk Perumusan Kriteria Fakir Miskin. Jurnal Informasi vol 17, No. 01 Tahun (2012). Pusat Penelitian dan Pengembangan Kesejahteraan Sosial, 


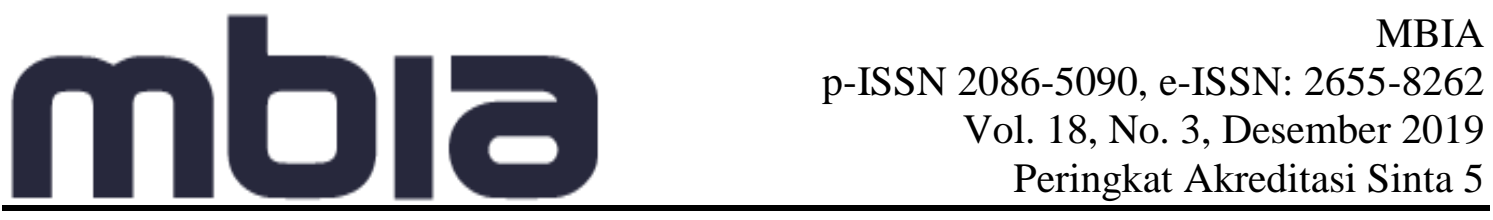

Kementrian Sosial Republik Indonesia

Bank Indonesia, Tinjauan Kebijakan Moneter: Ekonomi, Moneter, dan Perbankan (TKM), Maret 2008.

Binado, Ardito. Cetakan Oktober (2017). Penanggulangan Kemiskinan Dan Pemberdayaan Masyarakat, Penerbit Dee Publish.

Bramantyo Djohanputro, Prinsip-Prinsip Ekonomi Makro, (Jakarta: PPM, 2006).

Fauzi, A. (2007). Suatu Telaahan Masalah Kemiskinan di Indonesia. Makalah Jurusan Sosial Ekonomi Perikanan, FakultasPerikanan dan Ilmu Kelautan, Institut Pertanian Bogor. Bogor.

Hikmat, Harry.(2004). Strategi Pemberdayaan Pemberdayaan Masyarakat. Penerbit Humaniora Utama Press Bandung.

Ilyas Saad dan Irdham Ahmad. (2006). Kemiskinan di Indonesia : Pengertian, Dimensi dan Dinamika, BPFE, Yogyakarta, 2006.

Kaswan. (2013). Pelatihan dan Pengembangan Untuk Meningkatkan Kinerja SDM. Alfabeta.

Bandung

Kuncoro, Mudrajat.(2006).Ekonomika Pembangunan, Teori, Masalah dan Kebijakan. Edisi Keempat. Yogyakarta.UPP.AMP.YKPN 2004. Otonomi dan Pembangunan Daerah. Erlangga. Jakarta.

Kurniawan, Ferry Duwi dan Luluk Fauziah. (2014). Pemberdayaan Usaha Mikro Kecil dan Menengah (UMKM) dalam Penanggulangan Kemiskinan. Jurnal. Vol 2/N0. 2/09. Universitas Muhammadiyah Sidoarjo.

Prasetyo, Eko. (2008). Peran Usaha Mikro Kecil Dan Menengah (UMKM) Dalam Kebijakan Penanggulangan Kemiskinan dan Pengangguran Vol.2, Jurnal :UPY

Undang-Undang Republik Indonesia nomor 20 tahun 2008 tentang Usaha Mikro, Kecil dan Menengah

www.BPS Musi Rawas.go.id

\section{Acknowledgement}

Terima kasih penulis ucapkan kepada Kementrian Riset, Teknologi dan Pendidikan Tinggi yang telah memberikan dana hibah penelitian dosen pemula Tahun 2018/2019 kepada penulis sehingga penulis dapat menyelesaikan penelitian dan menghasilkan artikel ini.

\section{Copyright Disclaimer}

Copyright for this article is retained by the author(s), with first publication rights granted to the journal. 